\title{
Propaganda, Censorship, and Book Drives: The Newark Public Library in World War I \\ By George Robb
}

\section{DOI: http://dx.doi.org/10.14713/njs.v5i1.150}

This article examines the activities of the Newark Public Library during World War I as a means of highlighting the significant role American libraries played in promoting the nation's war effort. During the war public libraries were usually the most important information centers in their communities. They distributed books, pamphlets, and posters in support of a wide range of government initiatives, they organized war-related exhibits and classes, and they collected vast amounts of reading material for libraries at military camps. Newark's chief librarians, John Cotton Dana and Beatrice Winser, oversaw many such patriotic initiatives, but they also became involved in more controversial campaigns to employ women librarians at military camps and to resist wartime calls for censorship of unpatriotic literature.

In reviewing the activities of the Newark Public Library during World War I, this article highlights the important, but largely forgotten, role American libraries played in sustaining the nation's war effort. As the first "total war" of the twentieth century, World War I recruited civilians on the home front as actively as it recruited soldiers to fight overseas. ${ }^{1}$ While historians have written much about civilian initiatives involving women war workers, the Red Cross, victory gardens, and liberty loan drives, libraries' significant contributions to the war have received little scholarly attention. ${ }^{2}$ This is surprising, since an important aspect of total war was the control and

\footnotetext{
${ }^{1}$ For studies of the American homefront during World War I, see Christopher Capozzola, Uncle Sam Wants You: World War I and the Making of the Modern Citizen (New York: Oxford University Press, 2008); Celia Malone Kingsbury, For Home and Country: World War I Propaganda on the Homefront (Lincoln: University of Nebraska Press, 2010); and David M. Kennedy, Over Here: The First World War and American Society (New York: Oxford University Press, 1980).

${ }^{2}$ The most important works to examine libraries' contributions to the war are: Arthur P. Young, Books for Sammies: The American Library Association and World War I (Pittsburgh: Beta Phi Mu, 1981); and Wayne A. Wiegand, An Active Instrument for Propaganda: The American Public Library during World War I (Westport, CT: Praeger, 1989).
} 
dissemination of information (propaganda), and libraries at the time were important centers of information in any community. In an age before radio, television, and the internet, the books, periodicals, and newspapers freely available at public libraries were vital sources of knowledge. Libraries might also serve as gathering places, bulletin boards, art galleries, classrooms, and even warming centers on cold winter days. ${ }^{3}$

Most of the wartime activities of the Newark Public Library were characteristic of libraries all over the state of New Jersey and the nation as a whole in the years 1917-1918. Some initiatives, however, were unique to the Newark Library owing to its size and resources, or to the personalities of its librarians. Typically, the Library circulated books related to the war and distributed government pamphlets on gardening, canning, diet, and wartime cookery. The Library provided meeting space for patriotic organizations, held classes on food conservation and knitting, sold war bonds, and organized several war-related exhibits. The Newark Library collected thousands of books for servicemen at military camps in America and overseas. Librarians at Newark also became embroiled in two high-profile wartime controversies. Beatrice Winser, the Assistant Librarian, campaigned aggressively for women's employment as military camp librarians, against the wishes of the Librarian of Congress. Head Librarian John Cotton Dana came under fire for refusing to remove from the Library's shelves several books deemed unpatriotic. Dana's censorship battle drew national attention and threatened to overshadow the Library's other, more celebrated, war work.

America's libraries and librarians embraced their wartime role as purveyors of patriotic information, which they also believed would increase their visibility and prestige within their

\footnotetext{
${ }^{3}$ For discussions of libraries' importance in early $20^{\text {th }}$-century America, see Wayne A. Wiegand, Part of Our Lives: A People's History of the American Library (New York: Oxford University Press, 2017), Chapter 4; and Dee Garrison, Apostles of Culture: The Public Librarian and American Society, 1876-1920 (New York: Macmillan, 1977), Chapter 13.
} 
communities. The American Library Association (ALA), founded in 1876 at the time of the nation's centennial, saw the war as a great opportunity for libraries to demonstrate their importance to American society. ${ }^{4}$ At the ALA's annual meeting in June 1917, the Association's War Library Committee argued that "the entrance of the United States into the war is based on an idea. We can help foster ideas by books." The Committee also believed that libraries could increase the "efficiency" of civilian workers and encourage "the accumulation of historically valuable material growing out of the war." At the ALA's annual meeting in 1918, librarian Charles Alexander boasted that "in the ability to reach, educate and affect the adult population, the library occupies a position of great power for national defense."5

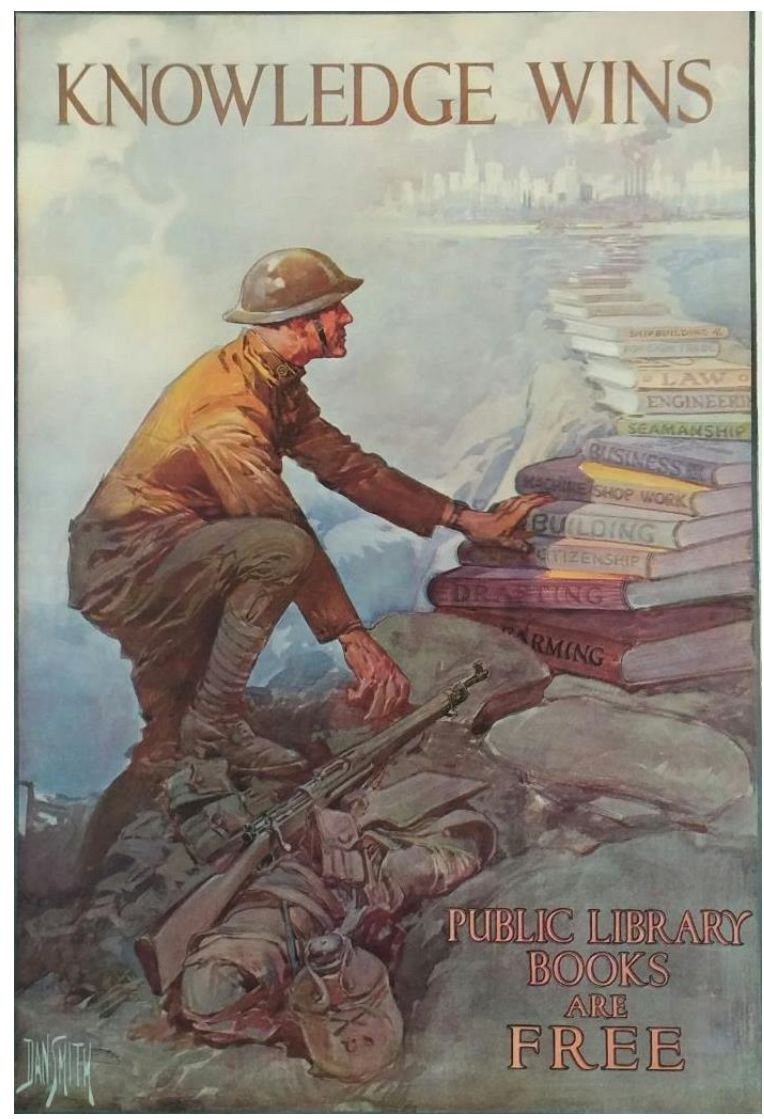

“Knowledge Wins,” Dan Smith, 1918 Library of Congress
Librarians created their own propaganda, which clearly indicates their sense of an exalted mission. One war poster produced for the American Library Association is entitled “Knowledge Wins.” Painted by artist Dan Smith, the poster depicts an American soldier climbing a staircase of books, labeled "law," "citizenship," "ship building," and "engineering." Such knowledge, freely provided by public libraries, would lead our soldiers to victory and to a brighter future, symbolized by a gleaming city at the end of the trail of books. Librarians saw their mission to

\footnotetext{
${ }^{4}$ Wiegand, An Active Instrument for Propaganda, 5.

${ }^{5}$ American Library Association Bulletin 11 (1917), 321-24; and American Library Association Bulletin 12 (1918), 49-50.
} 
educate and uplift as vital to the project of American democracy, and once the United States entered the war in 1917, it represented the struggle as a war for democracy and freedom against German militarism and oppression. ${ }^{6}$

There were tensions, however, between libraries' role as purveyors of knowledge and neutral information and a wartime emphasis on one-sided propaganda. Allied propaganda characterized German "Kultur" as brutal and unenlightened. The German army's destruction of the Belgian University of Louvain and its medieval library (among the oldest in Europe) was deeply shocking to teachers, librarians, and cultured people around the world. Widely-circulated photos of the ruined library offered a stark contrast to the American Library Association's propaganda posters. Germans burned books, while Americans read them to sustain our liberty. ${ }^{7}$

The anti-German atmosphere of the war years contrasted sharply with an earlier view of Germany as a center of the arts and sciences. Newark Librarian John Cotton Dana was an admirer of German culture and as recently as 1912 had mounted an exhibit of modern German applied art. Assistant Librarian Beatrice Winser had been educated in Germany and began her career in Newark as cataloger of German books. The city also had a large, prosperous, and well-established German-American community. Unlike other American libraries, Newark did not remove German language books or books by German authors during the war. As Dana's biographer, Frank Kingdon, later noted with approval, “German books stayed on the Library's shelves as evidence that a contemporary struggle could blot out neither past accomplishment nor future promise in the

\footnotetext{
${ }^{6}$ For ALA posters, see Walton Rawls, Wake Up, America!: World War I and the American Poster (New York: Abbeville, 1988), 157-59.

${ }^{7}$ For example, Professor James W. Garner of the University of Illinois described the German destruction of Louvain as the worst military crime "since the burning of the Library of Alexandria." Nation 99 (8 October 1914), 431.
} 
fields of universal culture." ${ }^{\prime 8}$ While Newark's chief librarians resisted expressions of xenophobia, they nonetheless supported the war with enthusiasm.

The Newark Public Library was well situated to carry out war work. Founded in 1889, the library was New Jersey's second oldest (after Paterson), and, with nine branches and hundreds of employees, the largest in the state. The central library, completed in 1901, was a grand beaux arts building set in a park just north of downtown Newark. The library appeared as a secular temple of education and high culture, but was also seen as a democratic institution, as it was free and open to all. ${ }^{9}$

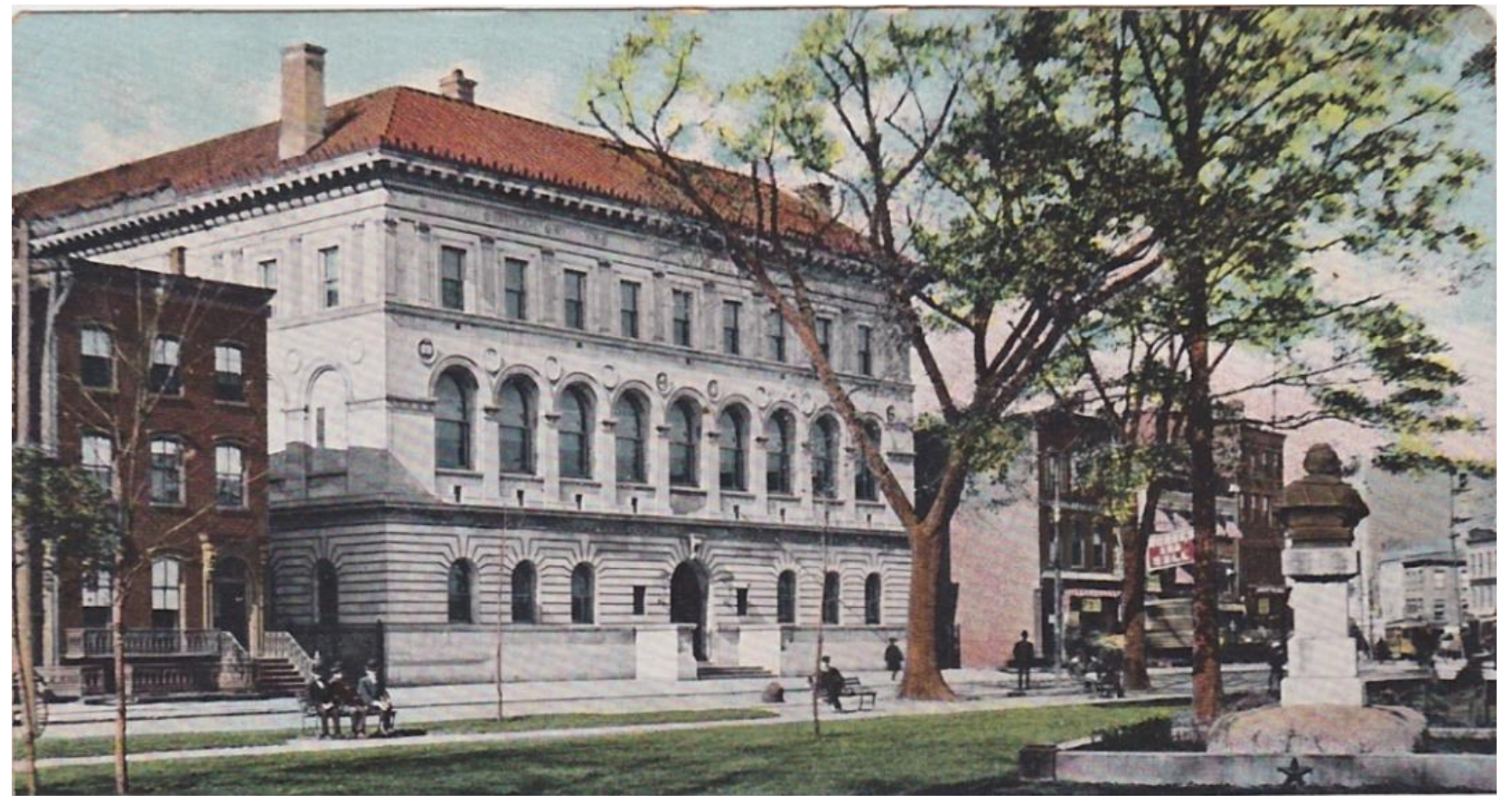

Newark Public Library, c. 1910 Author's Collection

Newark's chief librarians, John Cotton Dana and Beatrice Winser, certainly saw themselves as apostles of culture and progressive values. Dana came from distinguished New

\footnotetext{
${ }^{8}$ Frank Kingdon, John Cotton Dana: A Life (Newark: The Public Library and Museum, 1940), 141.

${ }^{9}$ For a brief history of the Newark Public Library, see Bruce E. Ford, "The Newark Public Library," in Edwin Beckerman, ed., A History of New Jersey Libraries, 1750-1996 (Lanham, MD: Scarecrow Press, 1997), 73-88.
} 
England forebears, including the Puritan divine Cotton Mather. After graduating from Dartmouth College in 1878, Dana worked as a librarian in Denver, Colorado and Springfield, Massachusetts. Winser was born in Newark, but raised in Germany, where her father served as a diplomat. She studied at Columbia Library School under Melvil Dewey, and she began her career at the Newark Public Library in 1889. So impressive were her administrative abilities that she rose to become Assistant Library Director by 1894 at age 26. When Dana arrived as the Library's second Director in 1902, he kept Winser on. They made a perfect team: he the intellectual and visionary, she the efficient business manager. Winser hired, fired, and managed the staff, oversaw the budget, and

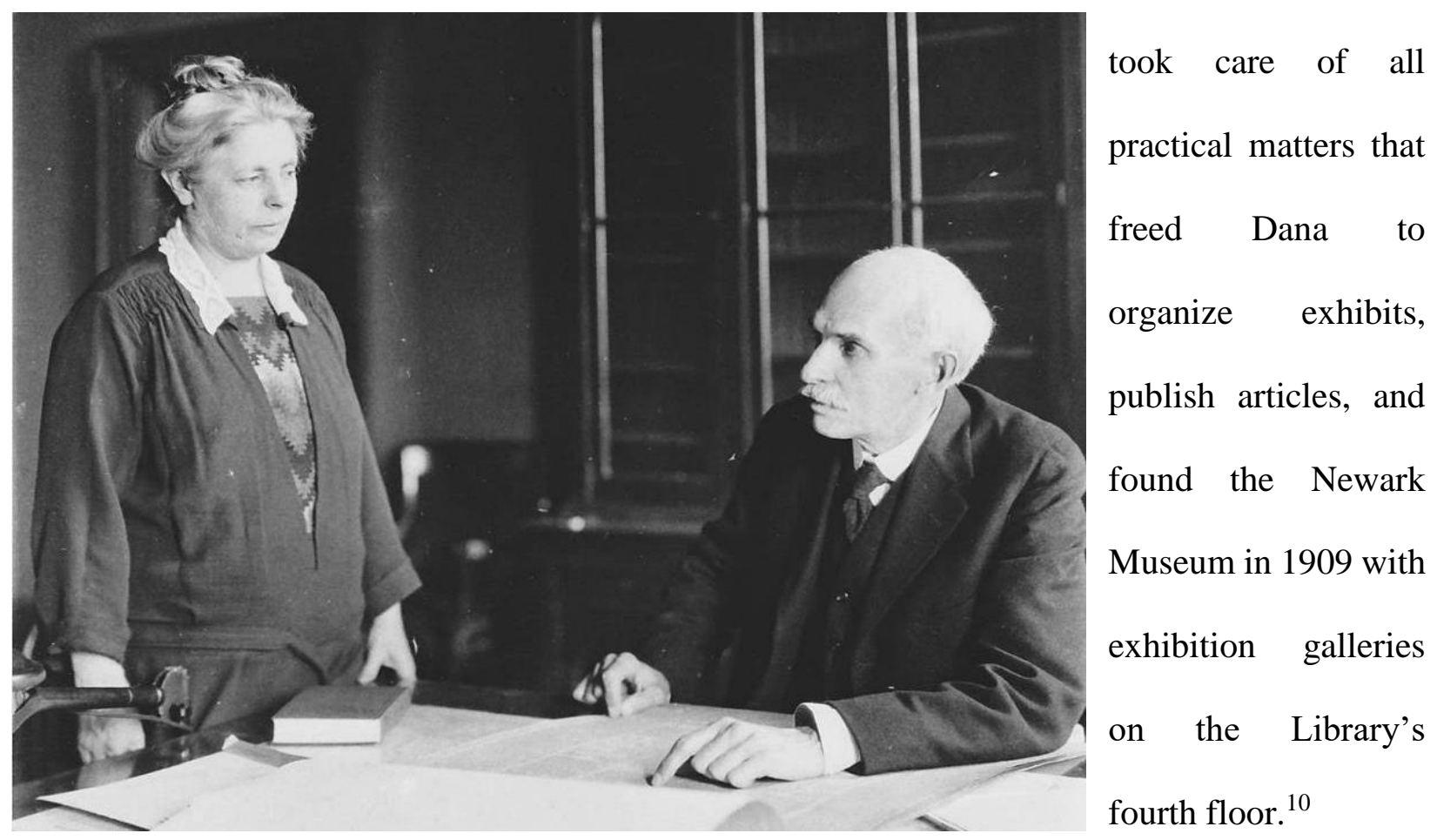

Beatrice Winser and John Cotton Dana, c.1920

Newark Museum, Archives

\footnotetext{
${ }^{10}$ For biographical information on John Cotton Dana and Beatrice Winser, see: Frank Kingdon, John Cotton Dana: A Life (Newark: The Public Library and Museum, 1940); Chalmers Hadley, John Cotton Dana: A Sketch (Chicago: ALA, 1943); Beatrice Winser, 1869-1947 (Newark: The Newark Museum, 1948); and Charlotte Perry-Dickerson, "Beatrice Winser," in Joan N. Burstyn, ed., Past and Promise: Lives of New Jersey Women (Syracuse: Syracuse University Press, 1997), 213-14.
} 
John Cotton Dana was well suited to support the war effort. He had already pioneered a wide variety of innovative methods of community outreach, such as using billboards to advertise library services or organizing the nation's first business library as a separate branch in Newark's business district. In 1912, Dana organized an Educational Loan Program, which annually lent thousands of scientific and historical objects to the city's schools for a "hands on" learning experience. Dana had famously railed against "the gloom of museums" that collected rare and expensive paintings and curios that were of no interest to the average American. He favored exhibits of applied art, industrial design, and science to educate Newark's schoolchildren and factory workers. Dana wanted the Library and Museum to serve the interests and needs of ordinary Newarkers, and war-related activities and programs fit nicely with this practical bent. ${ }^{11}$

Initially the war created serious constraints on the Library. The city of Newark slashed the Library's budget in 1918 to divert resources for the war. The Library had to close six of its branches and temporarily move 40,000 books to the central library, with makeshift shelving erected in corridors and galleries. The closed Roseville branch was re-purposed as a canteen for soldiers and sailors passing through Newark. Labor shortages soon developed, as members of the staff joined the military or took part in other war work, and wartime inflation eventually necessitated salary increases for the Library's remaining workers. Responding to War Department requests, librarians removed from the shelves certain books (such as those about explosives) that might aid enemy agents. $^{12}$

\footnotetext{
${ }^{11}$ For discussions of Dana's innovations as a library director, see Carol G. Duncan, A Matter of Class: John Cotton Dana, Progressive Reform, and the Newark Museum (Pittsburgh: Periscope Publishing, 2009), 22-47; and Ezra Shales, Made in Newark: Cultivating Industrial Arts and Civic Identity in the Progressive Era (New Brunswick: Rutgers University Press, 2010), 31-65. See also John Cotton Dana, "The Gloom of the Museum," in William A. Peniston, ed., The New Museum: Selected Writings of John Cotton Dana (Newark Museum Association, 1999), 4461.

${ }^{12}$ Minutes, Board of Trustees Meetings, November 8, 1917, January 30, 1918, April 17, 1918, Librariana II: Board of Trustees, Charles F. Cummings New Jersey Information Center, Newark Public Library. See also, The Library
} 
Undeterred, Dana and Winser rose to the occasion. They immediately created a "Library Information Bureau" as a clearinghouse for publications and information about the war. The reading room prominently displayed pamphlets, maps, posters, European newspapers, and books about everything from submarines and airplanes to Serbian history and first aid. Librarians maintained an extensive War Information File of newspaper clippings and government bulletins. A section devoted to New Books on the War highlighted hundreds of recent publications, many of which were continuously checked out. Lending Department staff reported that "war books were wanted all the time."13

The Reference Desk began fielding all manner of war-related questions. One patron wanted information on breakfast cereals that did not contain wheat (which the government was urging Americans to conserve). Artists who were producing patriotic posters requested images of soldiers, tanks, and artillery. Industrial firms in Newark asked librarians for statistics about the rising cost of living in the city in order to make wage adjustments for war workers. ${ }^{14}$

Long practiced in creative public outreach, John Cotton Dana found new ways to bring war-obsessed patrons into the Library. In a letter sent to all Newark high school students at the start of summer vacation in June 1917, Dana encouraged them to pursue activities "which will help to fit them to render intelligent service to their country." Above all, they should "get knowledge" by coming to the Library for "things to read, things to see, things to hear, things to do." 15 The Library also published a regular column in the local papers, "What Newarkers Are Reading," of the most in-demand books, which, in the summer of 1917, included H. G. Wells' war

and the Museum Therein 1 (July 1918), 2: this publication was launched by Dana in 1918 to better acquaint the residents of Newark with the Public Library's activities.

${ }^{13}$ The Library and the Museum Therein 1 (July 1918), 5.

${ }^{14}$ Ibid., 2.

${ }^{15}$ John Cotton Dana, letter to Newark students, June 25, 1917, Exhibition Files: War Exhibition, 1918, Box 14, Newark Museum Archives. 
novel, Mr. Britling Sees It Through, and Arthur Guy Empey's memoir of trench life, Over the Top. ${ }^{16}$ When patrons checked out books, librarians inserted bookmarks printed with patriotic advertisements, such as "Uncle Sam publishes 6,000 books to help You—and sends them free in most cases." During the bitterly cold winter of 1918, made worse by war-related fuel shortages, the Newark Library advertised that it was guaranteed a supply of coal and that the public should peruse the latest war books and "be warm.",17

\section{Save Food FOOD CONSERVATION WEEK DECEMBER I to 7, 1918}

Q The Library Information Bureau, Technical Department, 2nd floor, lends books and leaflets of recipes and suggestions for best uses of food.

I A Question Box for questions about recipes and general domestic economy, to be answered daily, is conducted by Miss Laura V. Clark, Newark Home Conservation office.

I Fireless cooker demonstration will be given by Miss Clark on Saturday afternoon, December 7. Fourth floor, Library Building.

The Free Public Library Newark, N.J.
Wartime food shortages were another problem tackled by America's libraries. In order to feed millions of servicemen and to supply our hard-pressed overseas allies, Americans were asked to restrict their consumption of wheat, meat, and sugar and to grow victory gardens. ${ }^{18}$ The U.S. Food Administration ran a food conservation campaign through public libraries. In Newark, the Library Information Bureau stocked books and pamphlets on gardening, canning, and wartime cookery. Librarians compiled leaflets of wheatless and meatless recipes and maintained a question box for inquiries about recipes and domestic economy. The "Save Food," 1918
Newark Public Library, Special Collections
Library also offered cooking classes taught by Laura Clark from the Newark Home Conservation Office. ${ }^{19}$

\footnotetext{
16 "What Newarkers Are Reading," Newark Evening News, August 18, 1917.

17 "Go to the Library to See Things and Be Warm," Newark Sunday Call, January 20, 1918.

${ }^{18}$ For the history of World War I food conservation programs, see Kingsbury, For Home and Country, Chapter 1; and Helen Zoe Veit, Modern Food, Moral Food (Chapel Hill: University of North Carolina Press, 2013), Chapter 3. ${ }^{19}$ Wiegand, An Active Instrument for Propaganda, 71-81.
} 
In January 1918, Sarah Askew, State Director of Library War Work for New Jersey, requested the Newark Public Library to put together an exhibit on food conservation. Entitled "Food Saving," the exhibit utilized posters, cartoons, and photographs to show visitors how to prepare low-cost and nutritious meals using foods like fish and legumes instead of meat and molasses instead of sugar. The exhibit opened at the Newark Library in March and then travelled to other libraries around New Jersey. ${ }^{20}$

Over the course of the war, the Library organized several other patriotic exhibits in its regular exhibition spaces on the second and third floors as well as in the Newark Museum's galleries on the fourth floor. The "Soldiers and Sailors" exhibit, which opened in March 1918, was the most popular. Dana explained that this exhibit "was planned to acquaint relatives and friends so fully with intimate details of the care and training given our men that anxiety for their welfare may give place to understanding and confidence." The Library had been collecting war posters and "souvenirs" like helmets and gas masks for a special archive, and this material became the basis for the "Soldiers and Sailors" show. ${ }^{21}$ Materials focused on the training of Newark conscripts at the newly built Camp Dix near Wrightstown, New Jersey. A much admired feature of the exhibit was a large scale model of Camp Dix built by Library employee Berthold Audsley. Audsley had to be given a special pass to wander around the camp unaccompanied lest his sketching and mapmaking be mistaken for the actions of a German spy. ${ }^{22}$

\footnotetext{
${ }^{20}$ Minutes, Board of Trustees Meeting, January 30, 1918, Librariana II: Board of Trustees, Charles F. Cummings New Jersey Information Center, Newark Public Library. See also, "Local Library Prepares Food Saving Exhibit to Move Around State," Newark Sunday Call, January 20, 1918; and Public Libraries 23 (March 1918), 150.

21 "Newark Museum Has a Plan to Collect War Souvenirs," Newark Sunday Call, December 23, 1917; and Newark Museum Annual Report (1917-18), 10-11.

22 "Exhibit at Public Library Will Show Model of Camp Dix," Newark Sunday Call, March 10, 1918; "Mimic Camp Dix at the Library, Newark Ledger, March 15, 1918; and The Library and the Museum Therein 1 (March 1919$), 13$.
} 


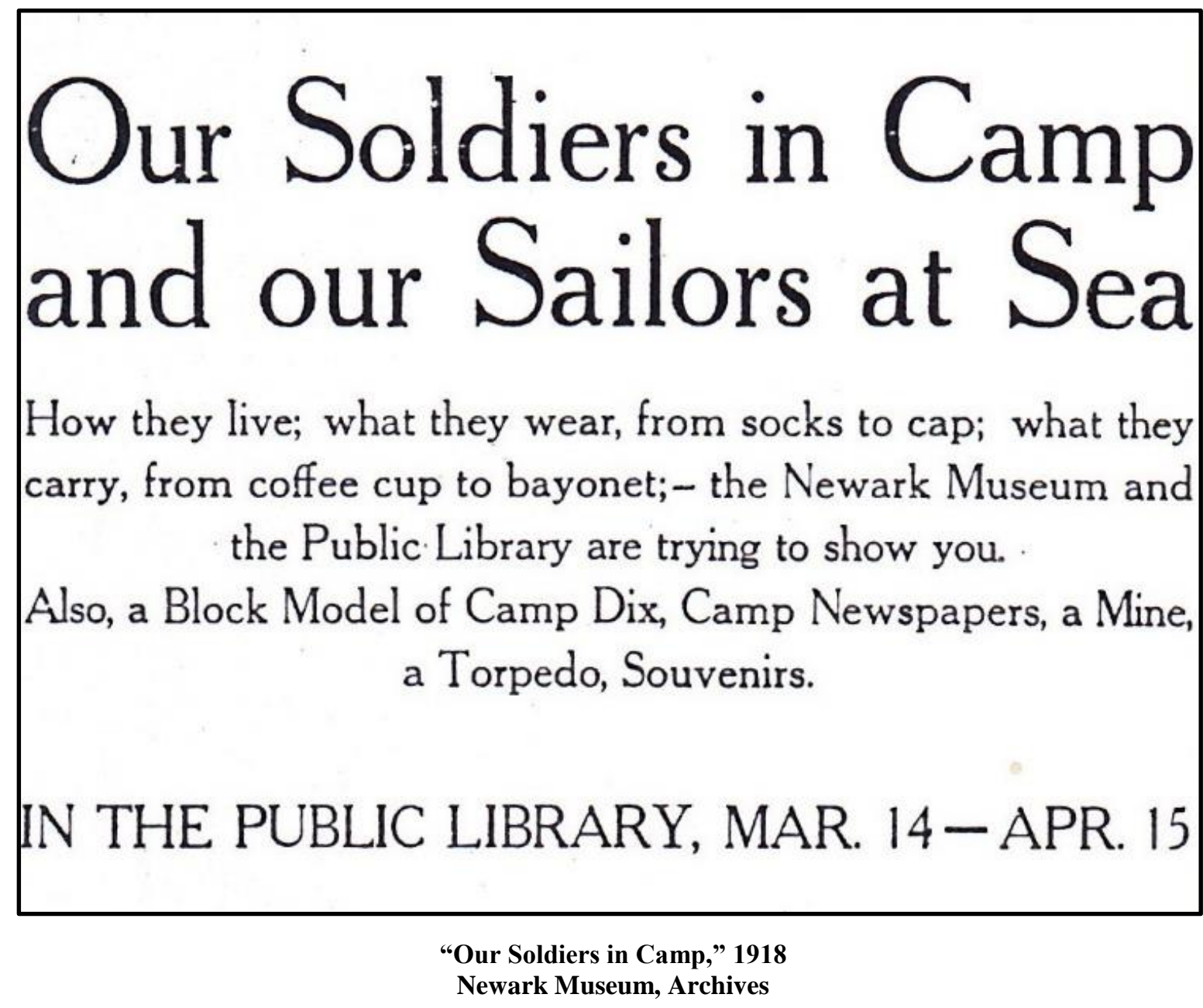

Another notable feature of the exhibit was a fully kitted-out uniform and equipment of an English soldier and an American soldier and sailor. The English uniform and kit were purchased from a London store, but the American uniforms proved much harder to come by. Initially, Dana wrote to the Quartermaster General of the U.S. Army and the Paymaster General of the Navy, requesting the loan of "the complete outfits of a common soldier and a common sailor." Apparently taken aback by their refusals, and discounting their excuses that, given the current needs of the war, no equipment could be spared, Dana appealed directly to Newton Baker, Secretary of War, and Josephus Daniels, Secretary of the Navy. They proved no more receptive, and, in the end, 
Dana purchased the uniforms from Bamberger's Department Store. The entire incident certainly illustrates Dana's persistence in carrying out his schemes. ${ }^{23}$

The Library organized several more patriotic exhibits, including a display of articles needed by the Red Cross and directions for making them and a display of government publications about the war. Other exhibits featured photographs from the Western Front, lithographs of American war industries by Joseph Pennell, and drawings by Louis Raemaekers, a Dutch artist who excelled at anti-German propaganda. ${ }^{24}$

The federal government was well aware of the Newark Public Library's energetic promotion of the war, and in July 1917, the Committee on Public Information in Washington asked Dana to organize a travelling exhibit of war posters for display in libraries and schools throughout the country. Dana selected forty posters from an assortment sent him by the CPI, supplemented by others from the Library's own collection. The exhibit was intended to inspire patriotism and to educate the public about America's war aims. ${ }^{25}$ Given his preference for applied over fine art, Dana also hoped to awaken the public to the posters' aesthetic qualities and practical advantages as mass media. Dana previously had organized exhibitions at the Newark Museum of artistic and commercial posters in 1914 and 1916. He had also purchased a hand press which he frequently used to produce posters advertising Library services and events. ${ }^{26}$ Dana tasked one of his staff members, Louise Connolly, to write an educational pamphlet, Posters and American War Posters, to accompany the exhibit. Connolly, a nationally known authority on pedagogy, also sought to

\footnotetext{
${ }^{23}$ John Cotton Dana, correspondence for "Soldiers and Sailors Exhibit," Exhibition Files: War Exhibition, 1918, Box 14, Newark Museum Archives.

24 "Pennell Lithographs Exhibited at Museum," Newark Star Eagle, January 15, 1918; "Red Cross Exhibit," Newark Ledger, December 5, 1918; and "Exhibit of Raemaekers Cartoons," Newark Sunday Call, August 19, 1917.

25 "War Posters Exhibit," Newark Sunday Call, July 22, 1917.

${ }^{26}$ For Dana's interest in posters and printing, see Shales, Made in Newark, 31-65, 119-31, 150-51, $256-57$.
} 
make the show interactive by creating a score card with which viewers could evaluate each poster's effectiveness and attractiveness. ${ }^{27}$ So successful was the entire endeavor that Dana was asked to organize a second, larger, exhibit in 1918. These shows were widely covered by the nation's press, and they travelled to 37 different towns as far afield as Los Angeles and Fargo, North Dakota. ${ }^{28}$

Another major wartime service of American libraries (Newark included) was to organize book drives to collect reading material for military camp libraries across the United States and overseas. Reading was one of the main leisure activities at military bases, but most were located in rural areas far from public libraries or bookstores. The American Library Association (ALA) created a War Service Committee to organize camp libraries for servicemen. The Committee, under the direction of Herbert Putnam, Librarian of Congress, was comprised of a dozen distinguished American librarians, including Frank Hill, Director of the Brooklyn Public Library and Dana's predecessor at Newark. Camp libraries were set up within YMCA facilities at military bases, but the library staff and the books were furnished by the ALA. By the summer of 1918, there were 41 camp libraries in the United States employing more than 200 librarians. $^{29}$

Initially, all camp library positions were going to men, much to the chagrin of female librarians who were eager to do their bit for Uncle Sam. The sexist hiring policy seemed at odds both with wartime labor practices, where women frequently took the place of men who were in the military, and with the statistics of the library profession, where ninety percent of personnel were women. ${ }^{30}$ Beatrice Winser, Assistant Director of the Newark Public Library, was especially

\footnotetext{
${ }^{27}$ Posters and American War Posters (Newark: Free Public Library, 1917).

${ }^{28}$ The Library and the Museum Therein 1 (July 1918), 6; "War Posters," Christian Science Monitor, July 31, 1918; and "Exhibit of War Posters Next Week in this City," Johnstown Tribune, April 25, 1918.

${ }^{29}$ Theodore Wesley Koch, War Service of the American Library Association (Washington: Library of Congress, 1918); Young, Books for Sammies, 13-17; and "Camp Libraries," New York Evening Post, July 12, 1918.

${ }^{30}$ Wiegand, An Active Instrument for Propaganda, 2; and Young, Books for Sammies, 34. In a memo to librarians titled "What Can I Do to Help?" the Library War Service declared that "men or women" are needed to sort and ship books to military camps, but that only "men are needed to volunteer for camp library service." War Library Bulletin 1 (August 1917), 3.
} 
outraged by the exclusion of female librarians from library war service. A suffragist and staunch advocate for women's rights, Winser made it her mission to overturn the ban.

In February 1918 Winser wrote directly to Secretary of War Newton Baker, asking him why women could work in camp hospitals and canteens, but not camp libraries. Baker passed her letter along to Herbert Putnam, the Librarian of Congress and head of the American Library Association's War Service Committee. Putnam replied to Winser that War Department regulations forbade the employment of women on military bases, which was, in fact, untrue. Putnam and other men in the ALA simply believed that women librarians were not up to the rigors of camp life. When Winsor discovered the truth, she wrote Putnam an angry letter, accusing him of being "deceitful" and of undervaluing women's abilities. She concluded: "The fundamental mistake made by you, Dr. Putnam ... seems to be the usual one of thinking men are better qualified than women for work in the world ... Let us not forget that women form a half of all democracies."31

Winser continued her campaign for equal opportunity in the pages of professional library journals and at the public meetings of the American Library Association. In June 1918 Winser wrote a letter to Public Libraries, responding to an article by James Wyer from the May 1918 issue of The Library Journal. Wyer was a member of the ALA's War Service Committee, and the article detailed his tour of 16 camp libraries. Regarding the employment of women librarians, Wyer concluded: “All our librarians agree that a camp library is a 'man's job' calling for the best ability and qualities in our very best men. There is nearly unanimous agreement that women can be largely used for assistants and for branches at base hospitals, and it is gratifying to record that the commanding officers are nearly all willing to allow women to be thus used." 32 In her response,

${ }^{31}$ Garrison, Apostles of Culture, 221.

32 J.I. Wyer, Jr., "Visit to Sixteen Military Camps,” The Library Journal 43 (May 1918), 339. 
Winser objected to the very idea that there were "men's jobs" and "women's jobs" in librarianship. She especially took issue with Wyer's belief that women could be "used" by men. According to Winser, Wyer's message to women was demeaning: "Dear women. You are not yet fit for 'man sized jobs,' nor can you be of yourselves 'useful,' but, if pliant, biddable, and intelligently docile, you can 'be used.'"33

The debate continued in the July 1918 issue of Public Libraries. John C. Sickley, a librarian at Camp Wadsworth in South Carolina, wrote to defend Wyer's position, arguing that most women lacked "the strength and endurance required for the service." Once more, Winser was withering in her response: "Superior physical strength does not necessarily endow men with superior gray matter, and it would seem to be high time for men to disabuse themselves of the notion, in spite of the present world cataclysm, that brute force is the only thing that moves the world." 34

Winser's persistence started to pay off. Although Herbert Putnam never publically backed down, he quietly began to admit women librarians to military camps and to employ more women at the Library War Service's headquarters in Washington. ${ }^{35}$ Some male camp librarians expressed support for Winser, such as Harold Brigham at Camp Dix, who in March 1918 wrote to her in praise of her "great Library War Service." Winser, however, penciled a skeptical "Ha!" in the letter's margin. ${ }^{36}$

Beatrice Winser and her supporters carried the fight for equality onto the floor of the American Library Association's annual meeting at Saratoga Springs, New York in July 1918. Winser and six other women librarians submitted a petition to the War Service Committee, asking

\footnotetext{
${ }^{33}$ Beatrice Winser, letter to the editor, Public Libraries 23 (June 1918), 267.

${ }^{34}$ John C. Sickley, letter to the editor, and Beatrice Winser, letter to the editor, Public Libraries 23 (July 1918 ), 315 16.

${ }^{35}$ Garrison, Apostles of Culture, 221.

${ }^{36}$ Harold Bingham, letter, March 27, 1918, Exhibition Files: War Exhibition, 1918, Box 14, Newark Museum Archives.
} 
it to clarify its policy "as to the employment of women in the work under its charge." During a Special General Session on July 4, James Wyer responded that there was no policy, but that the Library War Service now employed 236 men and 69 women, 40 of whom worked in camp libraries. Another member of the War Service Committee, Frank Hill, praised women librarians' war service, but still noted obstacles to their employment such as "exceptional physical hardships imposed and required" at military camps. Winser shot back: "We are getting excessively weary of being protected, shielded from hard work. We are quite accustomed in our own spheres to doing hard work of all kinds, so let us forget this cherishing of women in library work." After several more people spoke in favor of women's war work, Herbert Putnam thanked the women for their "manly expressions" of patriotism and brought the session to a close. ${ }^{37}$

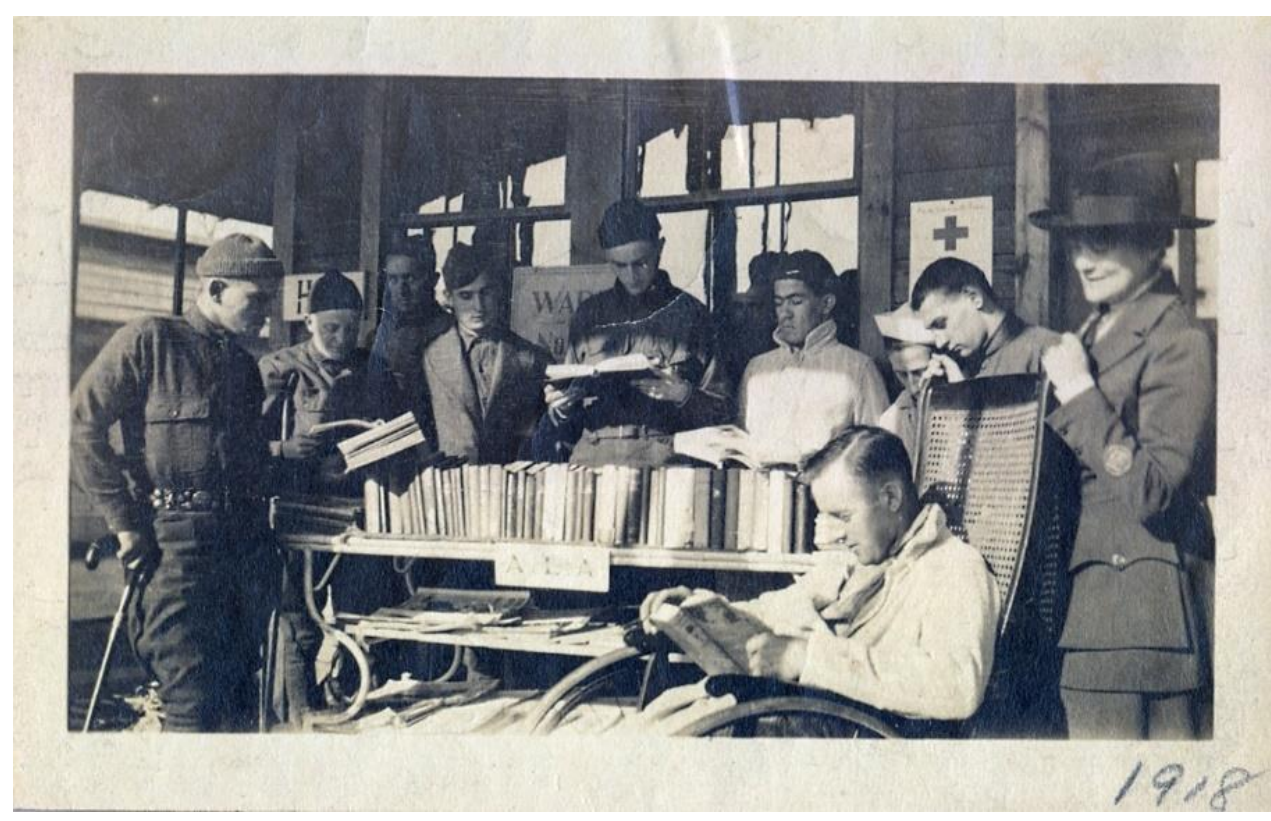

Woman librarian at Camp Dix, 1918

Library of Congress

${ }^{37}$ American Library Association Bulletin 12 (1918), 283-87. 
Winser and her allies had forced the Library War Service to reverse its opposition to women librarians at military instillations. By late 1918, women were actually in charge of eight camp libraries. Blanche Galloway, the first woman to head a camp library, at the Naval Training Station at Pelham Bay, New York, later reported that the men there had no problem "having a woman establish herself in their essentially masculine surroundings." 38

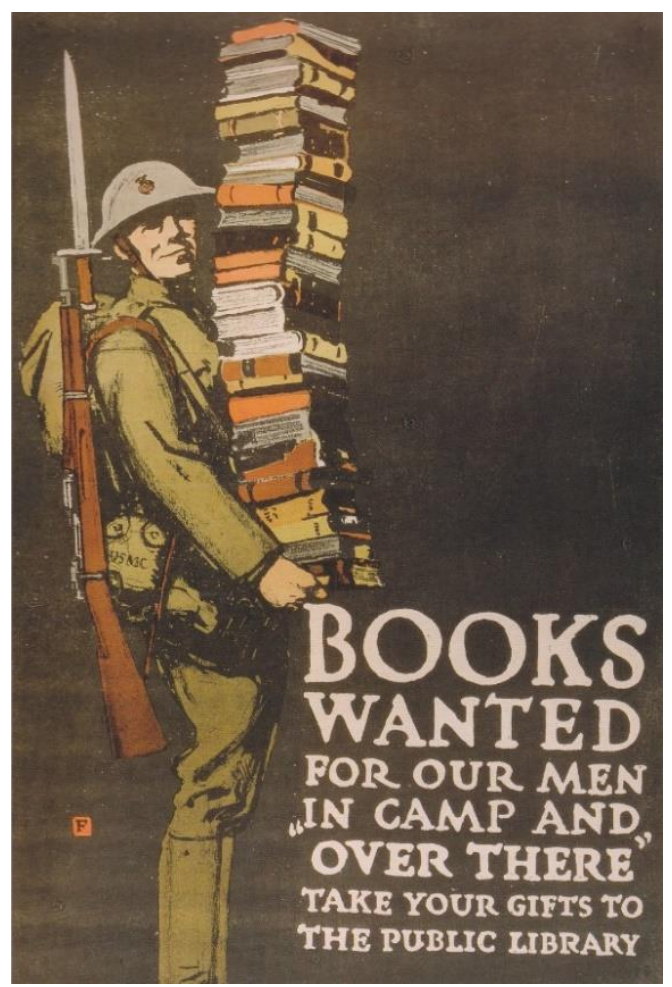

"Books Wanted"

Charles Buckles Falls, 1918

Library of Congress
Supplying the camp libraries was less controversial than staffing them, but no less daunting. Resources were to be provided by a war library fund, raised by popular subscription, and by national book drives, in which the American public would be asked to donate books. The War Service Committee produced some beautiful posters informing citizens that "Your Money Brings Books" and "Books Wanted for Our Men in Camp," but the ALA was a small organization, lacking the personnel and fund-raising experience of groups like the Red Cross, YMCA, and Salvation Army, that also undertook war work for the government. ${ }^{39}$

From Newark John Cotton Dana voiced doubts that the ALA's voluntary approach could gather sufficient funds or adequate reading material for all the nation's servicemen. As he noted: "In New Jersey alone demands come from forty-five different camps, hospitals, and stations, and can be supplied by libraries in pitiably small degree." Dana believed that the federal government

\footnotetext{
${ }^{38}$ American Library Association Bulletin 12 (1918), 224.

${ }^{39}$ Young, Books for Sammies, 19-23.
} 
needed to assume greater responsibility for funding camp libraries. He also saw the need for books to educate servicemen in addition to providing entertainment and diversion. Dana advocated a system of "formal instruction" at military camps on "occupations and professions of every kind." The ALA alone could never oversee anything so ambitious. ${ }^{40}$

The Library War Committee's fund-raising got off to a rocky start. Initially, the Committee hoped to raise "a million dollars for a million books for a million soldiers" during the week of September 24-30, 1917. ${ }^{41}$ With little advance warning, cities scrambled to put together local councils. In Newark Mayor Thomas Raymond appointed a group of distinguished citizens to oversee the campaign. In addition to Dana and Winser, Newark's "Library War Council” included wealthy businessmen like brewer Christian Fiegenspan and department store magnate Felix Fuld as well as religious leaders like Rabbi Solomon Foster of Temple B'nai Jeshurun and the Reverend Charles Gomph of Grace Episcopal Church. The Council organized a system of "flying squadrons" to fan out across the city with pledge forms. By the end of the week, Newark had only raised $\$ 2,500$ out of its stated goal of $\$ 20,000$, and the drive had to be extended another week. City fathers bemoaned Newark's inability to meet its allotted quota as a "great municipal degradation," but similar shortfalls occurred in numerous other cities. During the war, Americans were bombarded with endless appeals for money, and they apparently favored the Red Cross and Liberty Bonds over book funds. ${ }^{42}$

Far better results were achieved by the American Library Association's book drives. To supplement book purchases, the ALA conducted two wartime campaigns, in September 1917 and

\footnotetext{
40 John Cotton Dana, “The Use of Print in Making War-and Peace,” The Library Journal 43 (August 1918 ), 580.

${ }^{41}$ Young, Books for Sammies, 20.

42 "War Library Body Named by Mayor," Newark Evening News, September 19, 1917; and "War Library Campaign to Run Another Week," Newark Evening News, September 28, 1917.
} 
March 1918, netting more than 4 million books donated by the public. ${ }^{43}$ Here Newarkers proved more generous, contributing more than 40,000 books and 200,000 magazines over the course of the war. The book drives were massive undertakings, overseen by the Newark Public Library and assisted by the Mayor's Committee of Women and other civic organizations and businesses. ${ }^{44}$

Calls went out through the city for book donations. American Library Association posters blanketed the streets. Advertisements were placed in local papers, and placards in shop windows. The United Advertising Corporation of Newark built, free of charge, a billboard on the north side

Look for a sign like this in stores in your neighborhood and take your Books to the nearest one:

ARMY AND NAVY

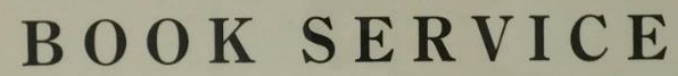

Leave your Books and Magazines here

Maryors Committee of Women of the Cuancil of National Detense The Newark Free Public Library May, 1918 of the Library, calling for "Books for Servicemen.” Dana designed and printed a special appeal: "There are a million men overseas. They want books . . Haven't you read your Christmas books? Won't you give yours and get your neighbor to give theirs? Send them to the Public “Army and Navy Book Service," 1918 Newark Public Library, Special Collections
Library for shipment." 45

Patrons brought donations to the main library on Washington Park. Boy Scouts went door to door in Newark, collecting books and magazines. People could leave books at schools and churches and at collection centers in each of the city's sixteen wards, especially drug stores, which were open late and often served as neighborhood gathering spots. Bamberger's Department Store

\footnotetext{
${ }^{43}$ Young, Books for Sammies, 25-27.

44 "How the Soldier and Sailor Books Come and Go," The Library and the Museum Therein 1 (July 1918 ), 14.

45 "Book Campaign to Start Today," Newark Sunday Call, March 10, 1918; and Minutes, Board of Trustees Meeting, April 17, 1918, Librariana II: Board of Trustees, Charles F. Cummings New Jersey Information Center, Newark Public Library.
} 
lent its delivery trucks to pick up books at collection centers and bring them to the Library for sorting. In September 1917 alone, the Library received 4,000 books and almost seven tons of magazines. In June 1918, donations averaged 200 books and 1,500 magazines per day. Librarian Marguerite Gates worked full-time in processing the books, assisted by other staff members and volunteers from the public schools. ${ }^{46}$

While the book drives gathered vast quantities of reading material, the quality sometimes left something to be desired. Unsuitable material included outdated textbooks, children's stories, cookbooks, and needlepoint manuals, making librarians wonder whether some "people had seized this as an opportunity to clean out their rubbish piles." Whatever couldn't be used was sold for old paper, and the money added to the war book fund. The Library supplemented the public donations by purchasing additional books and contributing duplicates from its own collection. Once books had been cleaned and sorted, they were packed in crates and shipped to various military bases. ${ }^{47}$

Most of the books collected in Newark were sent to camp libraries in New Jersey, especially to Camp Dix, near Wrightstown, where many of Newark's Army recruits did their basic training. Other military instillations that received books from Newark included Camp Vail near Little Silver, Camp Merritt near Tenafly, Fort Hancock at Sandy Hook, and the Naval Training Station at Cape May. Occasionally the Newark Public Library sent books further afield, such as to Camp McClellan in Alabama, where the New Jersey National Guard was stationed early in the

\footnotetext{
46 "Book Campaign," Newark Sunday Call, May 19, 1918; "Women Collected 12,000 Books and Magazines for Soldiers," Newark Sunday Call, May 26, 1918; Minutes, Board of Trustees Meeting, September 27, 1917,

Librariana II: Board of Trustees, Charles F. Cummings New Jersey Information Center, Newark Public Library; and The Library and the Museum Therein 1 (July 1918), 14 and (June 1919), 16.

${ }^{47}$ Minutes, Board of Trustees Meeting, September 27, 1917, Librariana II: Board of Trustees, Charles F. Cummings New Jersey Information Center, Newark Public Library; American Library Association Bulletin 11 (1917), 103; and "Books for Soldiers," Newark Evening News, May 15, 1918.
} 
war. There were not many books at the camp, but when the chaplain, Warren P. Coon, appealed to Dana, the librarian sent dozens of crates immediately. ${ }^{48}$

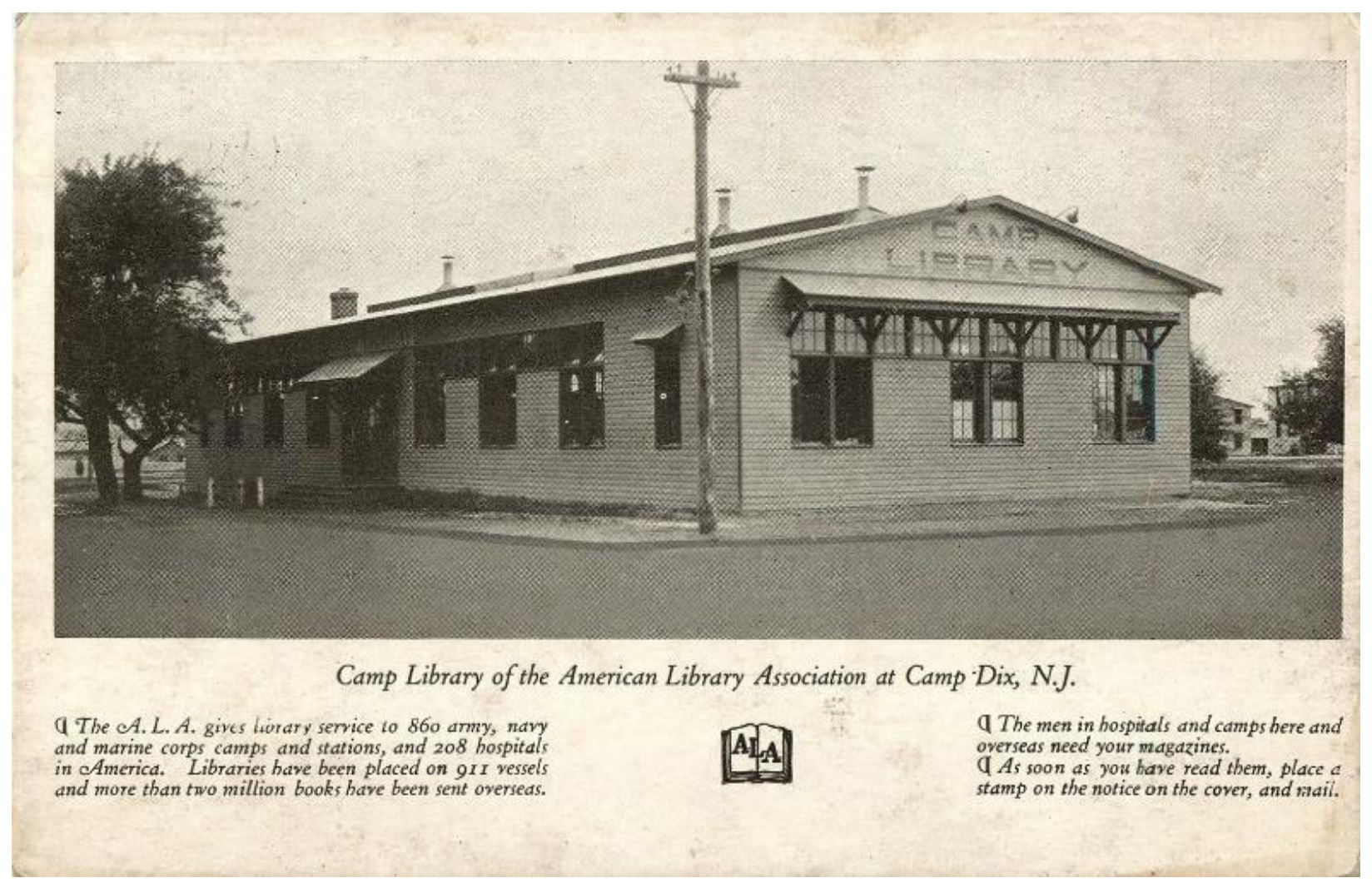

\section{Camp Dix Library, 1917 Author's Collection}

In March 1918, the Newark Sunday Call related a similar story in which Captain K. M. Bennett of the U.S.S. New Orleans, "read somewhere that the Newark Library was especially active among the libraries of the country in supplying books of value for soldiers and sailors." He wrote to Dana, asking for assistance, as the books on his ship were educational and not of much interest to the young men. Dana wrote back with "a list of books that would interest and amuse." He said that if the ship were ever in the vicinity, Captain Bennett should send sailors to the library,

\footnotetext{
${ }^{48}$ The Library and the Museum Therein 1 (July 1918), 14; and "Books for Camp McClellan," Newark Evening
} News, February 2, 1918. 
and they could "take away as many books as they could carry." Sometime later, when the New Orleans was docked in New York harbor, four sailors arrived at the Newark Public Library with Dana's letter. They left with 200 books stuffed in duffle bags. ${ }^{49}$

While winning praise for providing books to the troops, Dana was criticized for allowing certain "unpatriotic" books to remain on the Library's shelves. His refusal to remove library books that presented the German point of view was condemned by most commentators as hopelessly naïve or even treasonable. Although the American war effort was represented as a struggle for democracy and freedom, Americans' freedom of expression frequently came under attack, as the government and patriotic organizations suppressed pacifist, socialist, and German language publications. Not surprisingly, libraries sometimes became involved in questions of censorship. ${ }^{50}$

The story began for Newark in December 1917, when Marion Couthouy Smith, a poet from East Orange, New Jersey, began requesting libraries in the state to remove eight books she considered pro-German, including Frank Harris's England or Germany, James McGuire's The King, the Kaiser, and Irish Freedom, and Max Eastman's Understanding Germany. ${ }^{51}$ Smith was a member of the Vigilantes, a newly formed group of artists and writers which produced patriotic propaganda but also sought to suppress what they saw as un-American points of view. The books targeted by Smith were hostile to Britain and sympathetic to Germany, a fairly unobjectionable position during America's period of neutrality, but suddenly controversial now that the United

\footnotetext{
49 "Books for Sailors," Newark Sunday Call, March 3, 1918.

${ }^{50}$ For a discussion of censorship during World War I, see Capozzola, Uncle Sam Wants You, 164-69; and Alan Axelrod, Selling the Great War: The Making of American Propaganda (New York: Palgrave Macmillan, 2009), 6475.

${ }^{51}$ The other objectionable books were: Ernest F. Henderson, Germany's Fighting Machine; Edmund von Mach, Germany's Point of View; Edward Meyer, England: Her Political Organization and Development, and the War against Germany; Robert J. Thompson, England and Germany in the War; and Anthony Arnoux, The European War.
} 
States was Britain's ally and Germany's foe. Librarians in East Orange and Orange, New Jersey were happy to accommodate Marion Smith, but John Cotton Dana proved less obliging. ${ }^{52}$

When Smith asked Dana to remove the eight books from the Newark Library, he asked her to put her request in writing, giving her reasons. Her letter of December 4, later published, argued that the offending books "are not only morally wrong, but seditious, and even treasonable, at this critical juncture in our history. Whoever today sets himself against our Allies sets himself against the country our sons are about to die to defend-I am not an irresponsible trouble-maker, the Vigilantes include most of the best writers and fairest thinkers in America." Dana refused to remove the books, and his reply to Smith was brief: "I came to the conclusion (which I still hold) many years ago that liberty of thought is a very desirable thing for the world and that liberty of thought can only be maintained by those who have free access to opinion." Smith appealed to the Library's Board of Trustees, who upheld Dana. ${ }^{53}$

While Dana's position might seem unobjectionable, even praiseworthy, today, in the hyper-patriotic atmosphere of 1917-1918, it was almost unique. Most American librarians were keen to prove their patriotism by pulling anything critical of the war off their shelves. A number of libraries went so far as to remove all German language books or all books by German authors. In some cases, they even burned the books. ${ }^{54}$ The Newark controversy gave rise to additional inspections of libraries across the nation and to further removal of "disloyal” literature. Librarians'

\footnotetext{
${ }^{52}$ For a detailed discussion of the episode, see Wiegand, An Active Instrument for Propaganda, 95-99. For more information about the Vigilantes, see John Carver Edwards, “America's Vigilantes and the Great War, 1916-1918," Army Quarterly and Defense Journal 106 (1976), 277-86.

53 “Authors Lose Fight Against Teuton Books," New York Tribune, January 11, 1918; and Minutes, Board of Trustees Meeting, December 19, 1917, Librariana II: Board of Trustees, Charles F. Cummings New Jersey Information Center, Newark Public Library.

${ }^{54}$ Wiegand, An Active Instrument for Propaganda, 6; and Capazzola, Uncle Sam Wants You, 167-70.
} 
eagerness to serve the needs of the state overrode any desire to defend principles of intellectual freedom. In fact, no one in the library community spoke up for Dana. ${ }^{55}$

The Vigilantes certainly refused to let the matter drop, carrying their crusade to the press, most of which sided with them against Dana. The New York Tribune kept the controversy alive for months, repeatedly denouncing the Newark Library for aiding Germany’s propaganda. Charles J. Rosebault, former editor of the New York Sun and spokesperson for the Vigilantes, insisted that his organization was "heart and soul for liberty of expression," but that in wartime, "all rights which weaken us or help the enemy" must be abridged. Poet and Vigilante member Bliss Carman suggested that Dana had been "misled into false academic extremism" and that the librarian's stubborn attitude "does not show a philosophic open-mindedness. It shows only reprehensible folly." $" 56$

Dana weathered the controversy because he had the support of his trustees and because the Newark Public Library had clearly done much exceptional work in support of the war. Nonetheless, Dana was soured by the experience. In a postwar essay, "Public Libraries as Censors," he referred obliquely to "a lady of avowed patriotic temperament" who belonged to "a group whose patriotism was shouted from the housetops." Dana insisted that "democracy can have no censor" and "that in so far as this country has suffered autocratic censorship in recent months, so far it has not been a democracy." 57

In the years following the war, John Cotton Dana was quite upbeat and boosterish about the Newark Public Library's contributions to the conflict. In official postwar publications like The

\footnotetext{
${ }^{55}$ Wiegand, An Active Instrument for Propaganda, 100-112.

56 "Books in Newark Public Library Aid Foe's Propaganda," New York Tribune, January 14, 1918; "Another Library Controversy," New York Times, January 12, 1918; and Wiegand, An Active Instrument for Propaganda, 97.

57 John Cotton Dana, "Public Libraries as Censors," The Bookman 49 (April 1919), 149, 152.
} 
Library and the Museum Therein, Dana proudly detailed the Library's patriotic fundraising, warrelated exhibits, and book drives for servicemen ${ }^{58}$ In private, he remained depressed by his brush with censorship and by similar incidents elsewhere. He lamented that "the war has shown us that we are quite uncivilized... When Mars is talking, books have to sit still. Librarians cannot prevent the breakdown of civilization!" ${ }^{59}$ Like many progressive Americans, Dana became disillusioned by the war and its unfulfilled promises of democratic reform and world peace. ${ }^{60}$

Despite Dana's reservations, the Library had forged important wartime links with civic organizations, businesses, and the government that would flourish in the coming years. Like other libraries across the state and nation, the Newark Public Library achieved an unprecedented level of visibility and influence during World War I. It served as a vital center of information and promoted key government initiatives such as food conservation. Librarians John Cotton Dana and Beatrice Winser received national attention for spearheading patriotic exhibits, book drives, and women's employment opportunities. The Library also amassed an impressive array of war-related materials which, one hundred years later, are still available to researchers in its New Jersey Information Center and Special Collections Division.

George Robb has been a professor at William Paterson University for more than twenty years. He is the author of several books and articles on social and cultural history, including most recently, Ladies of the Ticker: Women and Wall Street from the Gilded Age to the Great Depression. Robb is a board member of the Newark History Society and he is currently researching a history of the Newark homefront during World War I.

\footnotetext{
${ }^{58}$ The Library and the Museum Therein 1 (July 1918), 2-14 and (March 1920), 8.

${ }^{59}$ Quoted in Kingdon, John Cotton Dana: A Life, 92.

${ }^{60}$ Duncan, A Matter of Class, 35.
} 
The author would like to thank William Peniston, Librarian and Archivist of the Newark Museum, Thomas Ankner, Reference Librarian at the Newark Public Library's Charles F. Cummings New Jersey Information Center, and Nadine Sergejeff, Special Collections Librarian at the Newark Public Library, for their research assistance. Thanks are also due to Timothy Crist, Bruce Ford, and Gail Malmgreen for kindly reading and commenting on an earlier draft of this article. The anonymous reviewers for New Jersey Studies provided additional comments from which the article has benefitted. 